\title{
THE AESCULAPIAN SOCIETY OF SHEFFIELD
}

A MeEting was held at Sheffield University Senior Common Room Club on Wednesday, 12 April 1972, to found this society, whose aims are to promote interest in history as related to medicine. It was agreed that the society should be entitled 'The Aesculapian Society', which will meet twice yearly for dinner, followed by papers and discussion. Mr. James Hardman was elected President, and Dr. Ronald Church, Secretary. After dinner, Mr. W. J. Lytle read a paper on 'The History of Hernia', and Dr. R. B. Morton a paper on 'Bothwell'. The date of the next meeting was arranged for Wednesday, 8 November 1972.

\section{MEDICAL HISTORY}

THE January 1971 number of Medical History is now out of print. The Editor would be most grateful to receive any spare copies of this number.

\section{THE WELLCOME TRUST}

\section{DIRECTOR OF THE WELLCOME INSTITUTE OF THE HISTORY OF MEDICINE}

\begin{abstract}
Applications are invited for the post of Director of the Wellcome Institute of the History of Medicine, London. The Wellcome Trustees hope to fill the post in the course of 1973. Applicants should preferably be medically qualified and should have had professional training and experience in historical research. They should have an interest in the history of ideas in the development of medical science. The successful applicant would also be expected to lead the research undertaken in the Institute and be responsible for the activities of the staff in charge of the library and museum. Salary and Pension on university professorial scale, subject to negotiation.

Applications, together with curriculum vitae and the names of two referees should be addressed to The Director, The Wellcome Trust, 52 Queen Anne Street, London, W1M 9LA, to whom all other enquiries should be addressed.
\end{abstract}

